\title{
Порівняльні характеристики ТТД провідних футбольних клубів світу
}

\author{
Андрій Перцухов \\ Борис Без'язичний \\ Вікторія Худякова
}

Харківська державна академія фізичної культури, Харків, Україна

Мета: визначити модельні показники виконання техніко-тактичних дій командами високого рівня.

Матеріал і методи: реєстрація техніко-тактичних дій здійснювалася на прикладі ігор команд-учасниць Ліги чемпіонів УЄФА сезону 2020/2021. Всього було зареєстровано та проаналізовано 242138 техніко-тактичних дій в 25 іграх за участю команд «Манчестер Сіті» (Манчестер, Англія), «Челсі» (Лондон, Англія), «Олімпік» (Марсель, Франція), «Олімпіакос» (Пірей, Греція), «Порту»(Порту, Португалія), «Краснодар» (Краснодар, Росія), «Ренн»(Ренн, Франція), «Севілья» (Севілья, Іспанія), «Атлетіко» (Мадрид, Іспанія), «Боруссія» (Дортмунд, Німеччина), «Боруссія» (Менхенгладбах, Німеччина), «Реал» (Мадрид, Іспанія), «Парі Сен-Жермен» (Париж, Франція). Для вирішення поставлених завдань в роботі застосовувалися такі методи дослідження: аналіз науково-методичної літератури, реєстрація техніко-тактичних дій, методи математичної статистики.

Результати: в статті представлено дані, що характеризують особливості виконання захисних та атакувальних ТТД командами високого рівня за підсумками ігор Ліги чемпіонів УЄФА сезону 2020/2021. Розроблено модельні показники виконання передач м'яча (різних за призначенням, дистанції, напрямку, траєкторії, способу виконання), ударів у ворота (ногою та головою з різних зон футбольного поля), обведень суперника, єдиноборств за м'яч, відборів, перехоплень, вибивань м'яча, блокування ударів у ворота.

Висновки: дані проведеного дослідження свідчать про відмінності в структурі змагальної діяльності команд різного рівня в іграх Ліги чемпіонів УЄФА сезону 2020/2021. Команда-переможниця перевершувала своїх суперників майже за всіма показниками.

Ключові слова: футболісти, модельні показники, ТТД, передачі м'яча, удари, перехоплення, відбори.

\section{Вступ}

Відомо, що управління підготовкою футболістів повинно ґрунтуватися на використанні моделей $[6,12,13$, $22,27,29]$. При цьому існує декілька визначень поняття «модель», але всі автори визначають її як певний зразок, стандарт, еталон або орієнтир [5, 6, 22, 24].

Вивчення літературних джерел дозволило встановити, що для оцінки певних моделей фахівцями використовуються модельні характеристики $[1,8]$ та модельні показники $[5,6]$.

Модельні характеристики розглядаються як [1, 8, 22]:

- ідеальні характеристики стану спортсмена, при яких він може показати рекордні результати;

- показники (тести), підвищення результатів в яких веде до збільшення змагальних досягнень;

- окремі показники, що входять в склад моделі.

У свою чергу модельні показники футболістів підрозділяються на модельні показники спортивних можливостей, спортивної майстерності та змагальної діяльності [6].

Так, модельні показники спортивних можливостей включають в себе показники, що відображають морфологічні та функціональні особливості організму спортсменів. У теперішній час проведено досліджен- ня морфофункціональних особливостей футболістів, а саме:

- віку футболістів різних амплуа [14],

- габаритних розмірів тіла футболістів різного рівня та амплуа [2, 3, 9, 16, 23, 30],

- функціональної підготовленості футболістів різної кваліфікації [5, 15, 25, 32, 36, 34].

Модельні показники спортивної майстерності ґрунтуються на рівні різних сторін підготовленості футболістів:

- фізичній [6, 24, 31],

- технічній [7],

- тактичній $[17,19]$.

Модельні показники змагальної діяльності футболістів розробляються за підсумками контролю їх змагальної діяльності, який здійснюється у двох напрямках:

- реєстрація рухової активності [20, 26, 28, 33],

- реєстрація техніко-тактичних показників [8, 10, $17,18,24]$.

Аналіз доступної літератури дозволив вивчити та узагальнити відомості, які стосуються розробки моделей змагальної діяльності трьох рівнів: узагальнені моделі $[4,37]$, групові моделі $[17,35]$, індивідуальні моделі $[11,21]$.
Слобожанський науково-спортивний вісник, № 3(83), С. 68-76, doi:10.15391/snsv.2021-3.010 


\section{СЛОБОЖАНСЬКИЙ НАУКОВО-СПОРТИВНИЙ ВІСНИК}

Мета дослідження - встановити модельні показники виконання техніко-тактичних дій командами високого рівня.

\section{Матеріал і методи дослідження}

Для вирішення поставлених завдань в роботі застосовувалися такі методи дослідження: аналіз науково-методичної літератури, реєстрація техніко-тактичних дій, методи математичної статистики. Реєстрація техніко-тактичних дій здійснювалася на прикладі ігор команд-учасниць Ліги чемпіонів УЄФА сезону 2020/2021. Всього було зареєстровано та проаналізовано 25 ігор команд «Манчестер Сіті» (Манчестер, Англія), «Челсі» (Лондон, Англія), «Олімпік» (Марсель, Франція), «Олімпіакос» (Пірей, Греція), «Порту» (Порту, Португалія), «Краснодар» (Краснодар, Росія), «Ренн» (Ренн, Франція), «Севілья» (Севілья, Іспанія), «Атлетіко» (Мадрид, Іспанія), «Боруссія» (Дортмунд, Німеччина), «Боруссія» (Менхенгладбах, Німеччина), «Реал» (Мадрид, Іспанія), «Парі Сен-Жермен» (Париж, Франція). У команд-учасниць даного турніру реєструвалися такі ТТД: єдиноборства за верховий м'яч, відбирання м'яча, перехоплення м'яча, вибивання м'яча, блокування ударів, удари у ворота, обведення суперника, короткі та довгі передачі м'яча, навісні передачі м'яча в штрафну площу, передачі м'яча в розріз між захисниками та передачі м'яча під удар.

\section{Результати дослідження}

У таблиці 1 наведено середні кількісні показники командних ТТД команди «Манчестер Сіті» (фіналіст Ліги чемпіонів УЄФА сезону 2020/2021) та її командсуперниць.

3 таблиці видно, що футболісти команди «Манчестер Сіті» в іграх даного турніру суттєво перевершували своїх опонентів за кількістю дотиків до м'яча ( $\mathrm{t}=9,00$; $\mathrm{p}<0,001)$, передач м'яча ( $\mathrm{t}=6,44 ; \mathrm{p}<0,001)$, обведень суперника $(\mathrm{t}=3,11 ; \mathrm{p}<0,01)$ та ударів у ворота $(\mathrm{t}=3,78$; $\mathrm{p}<0,001)$. У свою чергу суперники команди «Манчестер Сіті» перевершували їх за кількістю відборів ( $\mathrm{t}=2,97$; $\mathrm{p}<0,01)$ та вибивань м'яча $(\mathrm{t}=2,84 ; \mathrm{p}<0,01)$.

У таблиці 2 представлено середні кількісні показники ТТД команди «Челсі» (переможець Ліги чемпіонів УЄФА сезону 2020/2021) та ї̈ команд-суперниць. Результати

Таблиця 1

Кількісні показники ТТД команди “Манчестер Сіті» (Манчестер, Англія) в іграх Ліги чемпіонів УЄФА сезону 2020/2021 (n=13)

\begin{tabular}{|c|c|c|c|c|c|c|}
\hline \multirow{2}{*}{ Техніко-тактичні дії } & \multicolumn{2}{|c|}{ Команда «МC» } & \multicolumn{2}{|c|}{$\begin{array}{l}\text { Команди- } \\
\text { суперниці }\end{array}$} & \multirow{2}{*}{$\mathrm{t}$} & \multirow{2}{*}{$\mathrm{p}$} \\
\hline & $X_{1}$ & $\mathrm{~m}_{1}$ & $\mathrm{X}_{2}$ & $\mathrm{~m}_{2}$ & & \\
\hline Торкання м’яча & 859,1 & 21,4 & 599,2 & 19,4 & 9,00 & $<0,001$ \\
\hline Передачі м’яча & 684,5 & 27,9 & 442,9 & 25,1 & 6,44 & $<0,001$ \\
\hline Обведення суперника & 22,6 & 2,0 & 15,0 & 1,4 & 3,11 & $<\mathbf{0 , 0 1}$ \\
\hline Удари у ворота & 13,0 & 1,4 & 6,5 & 1,0 & 3,78 & $<0,001$ \\
\hline Сдиноборства за верховий м'яч & 18,8 & 2,6 & 18,8 & 2,6 & 0,00 & $>0,05$ \\
\hline Відбори м’яча & 22,6 & 1,5 & 29,8 & 1,9 & 2,97 & $<\mathbf{0 , 0 1}$ \\
\hline Перехоплення м'яча & 9,0 & 1,1 & 10,5 & 1,2 & 0,92 & $>0,05$ \\
\hline Вибивання м’яча & 10,2 & 1,4 & 18,6 & 2,6 & 2,84 & $<\mathbf{0 , 0 1}$ \\
\hline Блокування ударів & 2,0 & 0,7 & 3,3 & 0,6 & 1,41 & $>0,05$ \\
\hline Блокування передач м'яча & 8,0 & 0,7 & 8,2 & 0,7 & 0,20 & $>0,05$ \\
\hline
\end{tabular}

Таблиця 2

Кількісні показники ТТД команди “Челсі» (Лондон, Англія) в іграх Ліги чемпіонів УЄФА сезону 2020/2021 (n=13)

\begin{tabular}{|c|c|c|c|c|c|c|}
\hline \multirow{2}{*}{ Техніко-тактичні дії } & \multicolumn{2}{|c|}{ Команда «Челсі» } & \multicolumn{2}{|c|}{$\begin{array}{l}\text { Команди- } \\
\text { суперниці }\end{array}$} & \multirow[t]{2}{*}{$\mathrm{t}$} & \multirow{2}{*}{$\mathrm{p}$} \\
\hline & $\mathrm{X}_{1}$ & $\mathrm{~m}_{1}$ & $\mathrm{X}_{2}$ & $\mathrm{~m}_{2}$ & & \\
\hline Торкання м’яча & 720,5 & 31,4 & 671,6 & 32,6 & 1,08 & $>0,05$ \\
\hline Передачі м’яча & 535,5 & 32,2 & 488,3 & 33,4 & 1,02 & $>0,05$ \\
\hline Обведення суперника & 18,0 & 1,9 & 18,5 & 2,4 & 0,16 & $>0,05$ \\
\hline Удари у ворота & 11,2 & 1,1 & 9,3 & 1,0 & 1,28 & $>0,05$ \\
\hline Сдиноборства за верховий м’яч & 31,2 & 2,2 & 31,2 & 2,2 & 0,00 & $>0,05$ \\
\hline Відбори м’яча & 24,2 & 2,3 & 24,8 & 2,2 & 0,19 & $>0,05$ \\
\hline Перехоплення м’яча & 11,2 & 1,1 & 10,5 & 1,0 & 0,47 & $>0,05$ \\
\hline Вибивання м’яча & 18,2 & 2,0 & 13,1 & 2,0 & 1,80 & $>0,05$ \\
\hline Блокування ударів & 3,2 & 0,6 & 2,6 & 0,5 & 0,77 & $>0,05$ \\
\hline Блокування передач м'яча & 10,5 & 1,0 & 8,2 & 0,7 & 1,88 & $>0,05$ \\
\hline
\end{tabular}


Таблиця 3

Кількісні показники ТТД команд “Манчестер Сіті» (Манчестер, Англія) та «Челсі» (Лондон, Англія) в іграх Ліги чемпіонів УЄФА сезону 2020/2021 (n=13)

\begin{tabular}{|l|c|c|c|c|c|c|}
\hline \multirow{2}{*}{ Техніко-тактичні дії } & \multicolumn{2}{|c|}{ Команда «МС» } & Команда «Челсі» & \multirow{2}{*}{$\mathrm{t}$} & \multirow{2}{*}{$\mathrm{p}$} \\
\cline { 2 - 6 } & $\mathrm{X}_{1}$ & $\mathrm{~m}_{1}$ & $\mathrm{X}_{2}$ & $\mathrm{~m}_{2}$ & & \\
\hline Торкання м’яча & 859,1 & 21,4 & 720,5 & 31,4 & $\mathbf{3 , 6 5}$ & $<\mathbf{0 , 0 1}$ \\
\hline Передачі м’яча & 684,5 & 27,9 & 535,5 & 32,2 & $\mathbf{3 , 5 0}$ & $<\mathbf{0 , 0 1}$ \\
\hline Обведення суперника & 22,6 & 2,0 & 18,0 & 1,9 & 1,67 & $>0,05$ \\
\hline Удари у ворота & 13,0 & 1,4 & 11,2 & 1,1 & 1,01 & $>0,05$ \\
\hline Сдиноборства за верховий м’яч & 18,8 & 2,6 & 31,2 & 2,2 & $\mathbf{3 , 6 4}$ & $<\mathbf{0 , 0 1}$ \\
\hline Відбори м'яча & 22,6 & 1,5 & 24,2 & 2,3 & 0,58 & $>0,05$ \\
\hline Перехоплення м’яча & 9,0 & 1,1 & 11,2 & 1,1 & 1,41 & $>0,05$ \\
\hline Вибивання м’яча & 10,2 & 1,4 & 18,2 & 2,0 & $\mathbf{3 , 2 8}$ & $<\mathbf{0 , 0 1}$ \\
\hline Блокування ударів & 2,0 & 0,7 & 3,2 & 0,6 & 1,30 & $>0,05$ \\
\hline Блокування передач м’яча & 8,0 & 0,7 & 10,5 & 1,0 & 2,05 & $>0,05$ \\
\hline
\end{tabular}

таблиці свідчать, що суттєвих відмінностей в показниках кількості ТТД команди «Челсі» та команд-суперниць виявлено не було.

У результаті порівняльного аналізу показників змагальної діяльності команд-фіналісток ЛЧ 2020/2021 у іграх даного турніру було встановлено (табл. 3), що за атакувальними ТТД переважали футболісти команди «Манчестер Сіті», а за захисними ТТД - футболісти команди «Челсі». у таблиці 4 представлено середні показники кількості ударів у ворота в іграх команди «Манчестер Сіті». Дані таблиці свідчать, що футболісти команди «Манчестер Сіті» в середньому за гру виконували значно більше ударів відносно своїх суперників.

У свою чергу аналіз кількісних показників ударів у ворота в іграх команди «Челсі» показує (табл. 5), що футболісти даної команди несуттєво перевершували своїх суперників за більшістю показників.

Таблиця 4

Кількісні показники ударів у ворота команди «Манчестер Сіті» (Манчестер, Англія) в іграх Ліги чемпіонів УЄФА сезону 2020/2021 (n=13)

\begin{tabular}{|l|c|c|c|c|c|c|}
\hline \multirow{2}{*}{ Удари у ворота } & \multicolumn{2}{|c|}{ Команда «МС» } & \multicolumn{2}{|c|}{$\begin{array}{l}\text { Команди- } \\
\text { суперниці }\end{array}$} & \multirow{2}{*}{$\mathrm{t}$} & \multirow{2}{*}{$\mathrm{p}$} \\
\cline { 2 - 6 } & $\mathrm{X}_{1}$ & $\mathrm{~m}_{1}$ & $\mathrm{X}_{2}$ & $\mathrm{~m}_{2}$ & & \\
\hline Загальна кількість ударів & 13,0 & 1,4 & 6,5 & 1,0 & $\mathbf{3 , 7 8}$ & $<\mathbf{0 , 0 0 1}$ \\
\hline Голи & 1,9 & 0,3 & 0,4 & 0,1 & $\mathbf{4 , 7 4}$ & $<\mathbf{0 , 0 0 1}$ \\
\hline В створ воріт (крім голів) & 5,7 & 0,6 & 1,8 & 0,3 & $\mathbf{5 , 8 1}$ & $<\mathbf{0 , 0 0 1}$ \\
\hline Повз ворота & 4,0 & 0,5 & 2,5 & 0,4 & $\mathbf{2 , 3 4}$ & $<\mathbf{0 , 0 5}$ \\
\hline В каркас воріт & 0,4 & 0,2 & 0,1 & 0,1 & 1,34 & $>0,05$ \\
\hline Заблоковані удари & 3,3 & 0,6 & 2,1 & 0,7 & 1,30 & $>0,05$ \\
\hline З площі воріт & 1,3 & 0,2 & 0,5 & 0,3 & $\mathbf{2 , 2 2}$ & $<\mathbf{0 , 0 5}$ \\
\hline 3 штрафної площі (крім площі воріт) & 7,0 & 0,7 & 3,4 & 0,6 & $\mathbf{3 , 9 0}$ & $<\mathbf{0 , 0 0 1}$ \\
\hline Із-за меж штрафної площі & 4,7 & 0,7 & 2,6 & 0,4 & $\mathbf{2 , 6 0}$ & $<\mathbf{0 , 0 5}$ \\
\hline Правою ногою & 5,9 & 0,9 & 3,5 & 0,7 & $\mathbf{2 , 1 0}$ & $<\mathbf{0 , 0 5}$ \\
\hline Лівою ногою & 5,4 & 0,6 & 2,2 & 0,4 & $\mathbf{4 , 4 4}$ & $<\mathbf{0 , 0 0 1}$ \\
\hline Головою & 1,6 & 0,3 & 0,8 & 0,2 & $\mathbf{2 , 2 2}$ & $<\mathbf{0 , 0 5}$ \\
\hline
\end{tabular}


Таблиця 5

Кількісні показники ударів у ворота команди «Челсі» (Лондон, Англія) в іграх Ліги чемпіонів УЄФА сезону 2020/2021 (n=13)

\begin{tabular}{|l|c|c|c|c|c|c|}
\hline \multirow{2}{*}{ Удари у ворота } & \multicolumn{2}{c|}{$\begin{array}{c}\text { Команда } \\
\text { «Челсі» }\end{array}$} & \multicolumn{2}{c|}{$\begin{array}{c}\text { Команди- } \\
\text { суперниці }\end{array}$} & \multirow{2}{*}{$\mathrm{t}$} & $\mathrm{p}$ \\
\cline { 2 - 7 } & $\mathrm{X}_{1}$ & $\mathrm{~m}_{1}$ & $\mathrm{X}_{2}$ & $\mathrm{~m}_{2}$ & & \\
\hline Загальна кількість ударів & 11,2 & 1,1 & 9,3 & 1,0 & 1,28 & $>0,05$ \\
\hline Голи & 1,8 & 0,4 & 0,3 & 0,1 & $\mathbf{3 , 6 4}$ & $<\mathbf{0 , 0 1}$ \\
\hline В створ воріт (крім голів) & 4,5 & 0,5 & 2,8 & 0,5 & $\mathbf{2 , 4 0}$ & $<\mathbf{0 , 0 5}$ \\
\hline Повз ворота & 4,1 & 0,7 & 3,2 & 0,4 & 1,12 & $>0,05$ \\
\hline В каркас воріт & 0,3 & 0,2 & 0,2 & 0,1 & 0,45 & $>0,05$ \\
\hline Заблоковані удари & 2,6 & 0,5 & 3,2 & 0,6 & 0,77 & $>0,05$ \\
\hline З площі воріт & 0,7 & 0,3 & 0,5 & 0,2 & 0,55 & $>0,05$ \\
\hline 3 штрафної площі (крім площі воріт) & 7,7 & 0,9 & 5,5 & 0,5 & $\mathbf{2 , 1 4}$ & $<\mathbf{0 , 0 5}$ \\
\hline Із-за меж штрафної площі & 2,8 & 0,5 & 3,3 & 0,6 & 0,64 & $>0,05$ \\
\hline Правою ногою & 5,9 & 0,7 & 4,6 & 0,4 & 1,61 & $>0,05$ \\
\hline Лівою ногою & 3,4 & 0,6 & 2,8 & 0,6 & 0,71 & $>0,05$ \\
\hline Головою & 1,8 & 0,3 & 1,8 & 0,4 & 0,00 & $>0,05$ \\
\hline
\end{tabular}

При цьому, у результаті порівняльного аналізу кількісних показників ударів у ворота (табл. 6) було встановлено, що гравці команди «Манчестер Сіті» майже за всіма показниками перевершували гравців команди «Челсі». Проте достовірно значимі відмінності виявлено нами лише в показниках кількості ударів у ворота із-за меж штрафної площі $(\mathrm{t}=2,21 ; \mathrm{p}<0,05)$ та кількості ударів лівою ногою $(t=2,36 ; p<0,05)$.

Таблиця 6

Кількісні показники ударів у ворота команд «Манчестер Сіті» (Манчестер, Англія) та «Челсі» (Лондон, Англія) в іграх Ліги чемпіонів УЄФА сезону 2020/2021 (n=13)

\begin{tabular}{|l|c|c|c|c|c|c|}
\hline \multirow{2}{*}{ Удари у ворота } & \multicolumn{2}{|c|}{ Команда «МС» } & \multicolumn{2}{|c|}{$\begin{array}{c}\text { Команда } \\
\text { «Челсі» }\end{array}$} & \multirow{2}{*}{$\mathrm{t}$} & \multirow{2}{*}{$\mathrm{p}$} \\
\cline { 2 - 5 } & $\mathrm{X}_{1}$ & $\mathrm{~m}_{1}$ & $\mathrm{X}_{2}$ & $\mathrm{~m}_{2}$ & & \\
\hline Загальна кількість ударів & 13,0 & 1,4 & 11,2 & 1,1 & 1,01 & $>0,05$ \\
\hline Голи & 1,9 & 0,3 & 1,8 & 0,4 & 0,20 & $>0,05$ \\
\hline В створ воріт (крім голів) & 5,7 & 0,6 & 4,5 & 0,5 & 1,54 & $>0,05$ \\
\hline Повз ворота & 4,0 & 0,5 & 4,1 & 0,7 & 0,12 & $>0,05$ \\
\hline В каркас воріт & 0,4 & 0,2 & 0,3 & 0,2 & 0,35 & $>0,05$ \\
\hline Заблоковані удари & 3,3 & 0,6 & 2,6 & 0,5 & 0,90 & $>0,05$ \\
\hline 3 площі воріт & 1,3 & 0,2 & 0,7 & 0,3 & 1,66 & $>0,05$ \\
\hline 3 штрафної площі (крім площі воріт) & 7,0 & 0,7 & 7,7 & 0,9 & 0,61 & $>0,05$ \\
\hline Із-за меж штрафної площі & 4,7 & 0,7 & 2,8 & 0,5 & $\mathbf{2 , 2 1}$ & $<\mathbf{0 , 0 5}$ \\
\hline Правою ногою & 5,9 & 0,9 & 5,9 & 0,7 & 0,00 & $>0,05$ \\
\hline Лівою ногою & 5,4 & 0,6 & 3,4 & 0,6 & $\mathbf{2 , 3 6}$ & $<\mathbf{0 , 0 5}$ \\
\hline Головою & 1,6 & 0,3 & 1,8 & 0,3 & 0,47 & $>0,05$ \\
\hline
\end{tabular}


Таблиця 7

Кількісні показники передач м'яча команди «Манчестер Сіті» (Манчестер, Англія) в іграх Ліги чемпіонів УЄФА сезону 2020/2021 (n=13)

\begin{tabular}{|c|c|c|c|c|c|c|}
\hline \multirow[t]{2}{*}{ Передачі м’яча } & \multicolumn{2}{|c|}{ Команда «МС» } & \multicolumn{2}{|c|}{$\begin{array}{l}\text { Команди- } \\
\text { суперниці }\end{array}$} & \multirow[t]{2}{*}{$\mathrm{t}$} & \multirow[t]{2}{*}{$\mathrm{p}$} \\
\hline & $\mathrm{X}_{1}$ & $\mathrm{~m}_{1}$ & $\mathrm{X}_{2}$ & $\mathrm{~m}_{2}$ & & \\
\hline Загальна кількість передач м’яча & 684,5 & 27,9 & 442,9 & 25,1 & 6,44 & $<\mathbf{0 , 0 0 1}$ \\
\hline Передачі м'яча в штрафну площу & 15,3 & 2,1 & 9,1 & 1,5 & 2,40 & $<0,05$ \\
\hline Довгі передачі м’яча & 39,3 & 1,7 & 47,4 & 3,7 & 1,99 & $>0,05$ \\
\hline Короткі передачі м’яча & 682,0 & 28,6 & 427,6 & 25,3 & 6,66 & $<\mathbf{0 , 0 0 1}$ \\
\hline Передачі м'яча верхом & 47,7 & 2,6 & 47,7 & 3,0 & 0,00 & $>0,05$ \\
\hline Передачі м'яча низом & 673,6 & 28,6 & 427,3 & 23,1 & 6,70 & $<0,001$ \\
\hline Передачі м'яча вперед & 409,4 & 14,0 & 287,8 & 13,1 & 6,34 & $<0,001$ \\
\hline Передачі м’яча назад & 305,5 & 15,6 & 185,1 & 11,0 & 6,31 & $<0,001$ \\
\hline Передачі м'яча вправо & 358,6 & 14,8 & 239,9 & 12,6 & 6,11 & $<\mathbf{0 , 0 0 1}$ \\
\hline Передачі м'яча вліво & 359,2 & 14,0 & 232,5 & 11,3 & 7,04 & $<0,001$ \\
\hline Передачі м’яча в зоні обороні & 105,5 & 9,6 & 184,6 & 14,8 & 4,48 & $<\mathbf{0 , 0 0 1}$ \\
\hline Передачі м'яча в середній зоні & 413,6 & 21,3 & 207,8 & 12,4 & $\mathbf{8 , 3 5}$ & $<0,001$ \\
\hline Передачі м’яча в зоні атаки & 202,2 & 12,3 & 82,6 & 7,9 & 8,18 & $<0,001$ \\
\hline
\end{tabular}

Аналіз кількісних показників передач м'яча команд-учасниць Ліги чемпіонів уєФА свідчить, що за цими показниками команда «Манчестер Сіті» значно перевершувала свої противників (табл. 7). Так, футболісти даної команди в середньому за гру виконували достовірно більше передач м'яча в штрафну площу команди суперників ( $t=2,40 ; p<0,05)$, коротких передач м'яча ( $t=6,66 ; p<0,001)$, передач м'яча низом $(t=6,70$; $\mathrm{p}<0,001)$, вперед $(t=6,34 ; \mathrm{p}<0,001)$, назад $(t=6,31$; $p<0,001)$, праворуч ( $t=6,11 ; p<0,001)$, ліворуч ( $t=7,04$; $\mathrm{p}<0,001)$, в середній зоні $(t=8,35 ; p<0,001)$ та у зоні атаки $(t=8,18 ; p<0,001)$.

У свою чергу, в іграх команди «Челсі» кількість передач м'яча, що були виконані гравцями цієї команди та їх суперниками не мали достовірно значимих відмінностей (табл. 8).

Таблиця 8

Кількісні показники передач м'яча команди «Челсі» (Лондон, Англія) в іграх Ліги чемпіонів УЄФА сезону 2020/2021 (n=13)

\begin{tabular}{|c|c|c|c|c|c|c|}
\hline \multirow[t]{2}{*}{ Передачі м’яча } & \multicolumn{2}{|c|}{$\begin{array}{c}\text { Команда } \\
\text { «Челсі» }\end{array}$} & \multicolumn{2}{|c|}{$\begin{array}{l}\text { Команди- } \\
\text { суперниці }\end{array}$} & \multirow[t]{2}{*}{$\mathrm{t}$} & \multirow[t]{2}{*}{$\mathrm{p}$} \\
\hline & $\mathrm{X}_{1}$ & $\mathrm{~m}_{1}$ & $\mathrm{X}_{2}$ & $\mathrm{~m}_{2}$ & & \\
\hline Загальна кількість передач м’яча & 535,5 & 32,2 & 488,3 & 33,4 & 1,02 & $>0,05$ \\
\hline Передачі м’яча в штрафну площу & 14,2 & 1,5 & 16,9 & 2,0 & 1,08 & $>0,05$ \\
\hline Довгі передачі м'яча & 50,5 & 2,4 & 58,8 & 3,4 & 1,99 & $>0,05$ \\
\hline Короткі передачі м'яча & 523,1 & 34,0 & 476,2 & 34,7 & 0,97 & $>0,05$ \\
\hline Передачі м’яча верхом & 48,2 & 1,8 & 56,2 & 3,8 & 1,90 & $>0,05$ \\
\hline Передачі м'яча низом & 525,4 & 33,6 & 478,8 & 32,9 & 0,99 & $>0,05$ \\
\hline Передачі м'яча вперед & 350,9 & 19,0 & 330,2 & 18,5 & 0,78 & $>0,05$ \\
\hline Передачі м'яча назад & 220,8 & 14,8 & 202,9 & 16,1 & 0,82 & $>0,05$ \\
\hline Передачі м'яча вправо & 290,4 & 16,3 & 269,9 & 18,3 & 0,84 & $>0,05$ \\
\hline Передачі м'яча вліво & 280,8 & 17,4 & 262,1 & 16,4 & 0,78 & $>0,05$ \\
\hline Передачі м'яча в зоні обороні & 125,9 & 10,6 & 122,7 & 12,0 & 0,20 & $>0,05$ \\
\hline Передачі м'яча в середній зоні & 288,8 & 18,3 & 266,4 & 23,4 & 0,75 & $>0,05$ \\
\hline Передачі м’яча в зоні атаки & 158,8 & 14,7 & 145,9 & 7,6 & 0,78 & $>0,05$ \\
\hline
\end{tabular}


Кількісні показники передач м'яча команд “Манчестер Сіті» (Манчестер, Англія) та “Челсі» (Лондон, Англія) в іграх Ліги чемпіонів УЄФА сезону 2020/2021 (n=13)

\begin{tabular}{|c|c|c|c|c|c|c|}
\hline \multirow[t]{2}{*}{ Передачі м'яча } & \multicolumn{2}{|c|}{$\begin{array}{c}\text { Команда } \\
\text { «MC» }\end{array}$} & \multicolumn{2}{|c|}{$\begin{array}{l}\text { Команда } \\
\text { «Челсі» }\end{array}$} & \multirow[t]{2}{*}{$\mathrm{t}$} & \multirow{2}{*}{$\mathrm{p}$} \\
\hline & $\mathrm{X}_{1}$ & $\mathrm{~m}_{1}$ & $\mathrm{X}_{2}$ & $\mathrm{~m}_{2}$ & & \\
\hline Загальна кількість передач м’яча & 684,5 & 27,9 & 535,5 & 32,2 & $\mathbf{3 , 5 0}$ & $<\mathbf{0 , 0 1}$ \\
\hline Передачі м'яча в штрафну площу & 15,3 & 2,1 & 14,2 & 1,5 & 0,43 & $>0,05$ \\
\hline Довгі передачі м’яча & 39,3 & 1,7 & 50,5 & 2,4 & 3,81 & $<0,001$ \\
\hline Короткі передачі м’яча & 682,0 & 28,6 & 523,1 & 34,0 & 3,58 & $<\mathbf{0 , 0 1}$ \\
\hline Передачі м'яча верхом & 47,7 & 2,6 & 48,2 & 1,8 & 0,16 & $>0,05$ \\
\hline Передачі м’яча низом & 673,6 & 28,6 & 525,4 & 33,6 & 3,36 & $<\mathbf{0 , 0 1}$ \\
\hline Передачі м'яча вперед & 409,4 & 14,0 & 350,9 & 19,0 & 2,48 & $<0,05$ \\
\hline Передачі м'яча назад & 305,5 & 15,6 & 220,8 & 14,8 & 3,94 & $<0,001$ \\
\hline Передачі м'яча вправо & 358,6 & 14,8 & 290,4 & 16,3 & 3,10 & $<0,01$ \\
\hline Передачі м'яча вліво & 359,2 & 14,0 & 280,8 & 17,4 & $3, \mathbf{5 1}$ & $<\mathbf{0 , 0 1}$ \\
\hline Передачі м'яча в зоні обороні & 105,5 & 9,6 & 125,9 & 10,6 & 1,43 & $>0,05$ \\
\hline Передачі м'яча в середній зоні & 413,6 & 21,3 & 288,8 & 18,3 & 4,44 & $<0,001$ \\
\hline Передачі м'яча в зоні атаки & 202,2 & 12,3 & 158,8 & 14,7 & 2,26 & $<0,05$ \\
\hline
\end{tabular}

У таблиці 9 представлено середні кількісні показники передач м'яча команд «Манчестер Сіті» та «Челсі» у 13 іграх Ліги чемпіонів УЄФА.

Аналіз отриманих даних свідчить, що футболісти «Манчестер Сіті» здійснювали значно більше коротких передач м'яча ( $t=3,58 ; p<0,01)$, передач м'яча низом $(t=3,36 ; p<0,01)$, вперед $(t=2,48 ; p<0,05)$, назад $(t=3,94$; $\mathrm{p}<0,001)$, вправо ( $t=3,10 ; \mathrm{p}<0,01)$, вліво $(\mathrm{t}=3,51 ; \mathrm{p}<0,01)$, в середній зоні $(\mathrm{t}=4,44 ; \mathrm{p}<0,001)$ та зоні атаки $(\mathrm{t}=2,26$; $\mathrm{p}<0,05)$. Футболісти команди «Челсі» перевершували своїх колег лише за показниками кількості довгих передач м'яча ( $t=3,81 ; p<0,001)$.

\section{Висновки/ Дискусія}

Дані проведеного дослідження свідчать про відмінності кількісних показників захисних та атакувальних техніко-тактичних дій в структурі змагальної діяльності кращих футбольних клубів Європи в іграх Ліги чемпіонів УЄФА сезону 2020/2021. Команда «Манчестер Сіті» (фіналіст Ліги чемпіонів УЄФА) в іграх даного турніру перевершувала своїх опонентів за показниками атакувальних ТТД. У свою чергу, команда «Челсі» (переможець
Ліги чемпіонів УЄФА) мала кращі показники виконання захисних ТТД.

Результати проведеного дослідження підтвердили інформацію щодо кількісних показників командних ТТД команд різного рівня (Шамардін В.Н., 2002, 2012, Костюкевич В.М., 2006). Доповнено та розширено дані щодо особливостей виконання атакувальних та захисних ТТД командами різного рівня (Перевозник В.І., Мулик В.В., Паєвський В.В., 2020, Перевозник В.І., Журід С.М., Марченко В.А., 2012, Перцухов А.А., 2018, 2020). Розроблено моделі змагальної діяльності кращих команд-учасниць Ліги чемпіонів УЄФА сезону 2020/2021. Положення та висновки даного дослідження можуть враховуватися при формуванні клубних та збірних команд різного рівня та при плануванні техніко-тактичної підготовки футболістів різної кваліфікації.

Перспективи подальших досліджень у даному напрямку. Подальші дослідження можуть бути присвячені встановленню особливостей виконання ТТД команд прем'єр-ліги чемпіонату України, першої та другої ліг першості України.

Конфлікт інтересів. Автори заявляють, що відсутній конфлікт інтересів, який може сприйматись таким, що може завдати шкоди неупередженості статті.

Джерела фінансування. Ця стаття не отримала фінансової підтримки від державної, громадської або комерційної організації.

\section{Список посилань}

1. Голомазов С., Чирва Б. (2000), «Модельные характеристики игры в штрафной площади», Теория и практика футбола, №2 (6), C. 2-4.

2. Голомазов С., Чирва Б. (2003), «Морфологические признаки вратарей высокой квалификации», Теория и практика футбола, №2 (18), С. 25-28 
3. Губа В., Кузьменко Ю., Строева И., Чернова В. (2001), «Морфологическая характеристика футболистов 17-18 лет», Теория и практика футбола, №3 (11), С. 17-19.

4. Журид С. Н. (2007), «Модельные характеристики технико-тактических действий юных футболистов 15 и 17 лет различных игровых амплуа», Слобожанський науково-спортивний вісник, №12, С. 93-97.

5. Костюкевич В. М. (2006), «Модельні показники функціональної підготовленості футболістів», Збірник наукових праць 3 галузі фізичної культури і спорту, №10, С. 78.

6. Костюкевич В. М. (2006), Управление тренировочным процессом футболистов в годичном цикле подготовки. Винница: Планер, 683 с.

7. Лебедєв С. І., Слеман Ребаз (2015), «Аналіз показників змагальної діяльності та спеціальної технічної підготовленості футболістів 10-12 років», Слобожанський науково-спортивний вісник, №5 (49), С. 52-56.

8. Максименко І. Г., Костюнін А. В. (2007), «Аналіз показників змагальної діяльності футболістів збірної команди України на чемпіонаті світу 2006», Слобожанський науково-спортивний вісник, № 11, С. 47-54.

9. Мартиросов Э., Балучи Р. (2006), «Морфологические особенности футболистов высокой квалификации разных амплуа», Футбол-Профи, №2, С. 60-65.

10. Мулик В. В., Перевозник В. І., Перцухов А. А. (2015), «Характеристика епізодів гри в штрафному майданчику команди суперника», Слобожанський науково-спортивний вісник, №3 (47), С. 75-79.

11. Перевозник В. И., Перцухов А. А. (2007), «Сравнительный анализ выполнения технико-тактических действий опытными футболистами и футболистами 17-19 лет», Слобожанський науково-спортивний вісник, №11, С. 115-119.

12. Перевозник В. И., Перцухов А. А. (2016), «Модельные показатели подготовленности футболистов высокой квалификации», Проблемы и перспективы развития спортивных игр и единоборств в высших учебных заведениях, С. 34-39.

13. Перевозник В. И., Перцухов А. А. (2017), «Модельные показатели соревновательной деятельности футболистов высокой квалификации», Проблемы и перспективы развития спортивных игр и единоборств в высших учебных заведениях, С. 41-45.

14. Перевозник В. И., Перцухов А. А. (2018), «Возрастные и антропометрические показатели футболистов высокой квалификации", Слобожанський науково-спортивний вісник, №6 (68). С. 65-69.

15. Перевозник В. И., Перцухов А. А. (2018), «Функциональная подготовленность футболистов высокой квалификации», Проблемы и перспективы развитие спортивных игр и единоборств в высших учебных заведениях, С. 60-65.

16. Перцухов А. А. (2011), «Взаимосвязь показателей габаритных размеров тела и функциональной подготовленности футболистов 17-19 лет», Физическое воспитание студентов, №4, С. 64-66.

17. Перцухов А. А. (2017), «Особенности выполнения передач мяча футболистами команды «Лестер Сити» в играх чемпионата Англии 2015-2016 гг.», Слобожанський науково-спортивний вісник, №3 (59), С. 101-105.

18. Перцухов А. А. (2018), «Характеристика результативных ударов в ворота в играх команд высокой квалификации», Спортивные игры, №2 (8), С. 54-60.

19. Перцухов А. А. (2020), «Інтенсивність та ефективність застосування пресингу футболістами команд високого рівня», Спортивні ігри: електронний науковий журнал, №2 (16), С. 50-57.

20. Перцухов А. А., Перевозник В. И. (2019), «Двигательная активность футболистов высокой квалификации в условиях соревновательной деятельности», Спортивные игры, №1 (11), С. 32-39.

21. Перцухов А. А., Шаленко В. В. (2021), «Модельні характеристики провідних футболістів різного ігрового амплуа», Слобожанський науково-спортивний вісник, №1 (81), С. 47-58.

22. Платонов В. Н. (2004), Система подготовки спортсменов в олимпийском спорте. Общая теория и ее практическое приложение. Киев: Олимпийская литература, 808 с.

23. Шаленко В. В., Перцухов А. А. (2016), «Антропометрические показатели футболистов высокой квалификации», Проблемы и перспективы развития спортивных игр и единоборств в высших учебных заведениях, С. 53-56.

24. Шамардин В. Н. (2002), Моделирование подготовленности квалифицированных футболистов. Днепропетровск: Пороги, $200 \mathrm{c}$.

25. Bangsbo J. (1993), The physiology of soccer - with special reference to intense intermittent exercise. HO + Storm, 155 p.

26. Bangsbo J. (1994), «Energy demands in competitive soccer», J. Sports Sci, №12, pp. 5-12.

27. Bangsbo J. (1998), «The physiological profile of soccer players», Sports Exercise and Injury, №4, pp. 144-150.

28. Bangsbo J., Norregaard L., Thorsoe F. (1991), «Activity profile of competition soccer», J. Sports Sci, №16 (2), pp. 6-110.

29. Brewel J., Davis J.A. (1992), «A physiological comparison of English professional and semi-professional soccer players», J. Sports Sci, №10, pp. 7-146.

30. Broad E.M., Burke L.M., Cox G.R., Heeley P, Riley M. (1996), «Body weight changes and voluntary fluid intakes during training and competition sessions in team sport», Int J Sport Nutr, №6 (3), pp. 20-307.

31. Casajus J.A. (2001), "Seasonal variation in fitness variables in professional soccer players», J. Sports Med. Phys. Fitness, №41 (4), pp. 9-463.

32. Davies J.A., Brewer J., Atkin D. (1992), «Preseasonal physiological characteristics of English first and second division soccer players», Journal of Sports Sciences, №10, pp. 541-547.

33. Dupont G., Akakpo K., Berthoin S. (2004), «The effect of in-season, high-intensity interval training in soccer players», J Strength Cond Res, №18 (3), pp. 9-584.

34. Heller J., Prochazka L., Bunc V. (1992), «Functional capacity in top league football players during the competitive season», J. Sports Sci, №10, p. 150.

35. Pertsukhov A., Beziazychnyi B., Khudiakova V. (2020), «Features of goal kicks by football players in games of high-level teams", Slobozhanskyi herald of Science and Sport, Vol 8, No 1, pp. 59-62.

36. Pertsukhov A., Perevoznick V., Shalenko V., Zhurid S., Khudyakova V., Koval S. (2018), «Functional preparedness of football players with different qualifications", The Journal of Physical Education and Sport is now a registered trademark (all rights reserved), №104, pp. 710-714.

37. Pertsukhov A., Shalenko V. (2020), «Features of effective goal shots by football players in games of high level teams», Slobozhanskyi herald of Science and Sport, Vol 8, No 2, pp. 17-28.

Стаття надійшла до редакції: 17.05.2021 р.

Опубліковано: 23.06.2021 р. 


\begin{abstract}
Аннотация. Андрей Перцухов, Борис Безъязычный, Виктория Худякова. Сравнительные характеристики ТтД ведущих футбольных клубов мира. Цель: определить модельные показатели выполнения технико-тактических действий командами высокого уровня. Материал и методы: регистрация технико-тактических действий осуществлялась на примере игр команд-участниц Лиги чемпионов УЕФА сезона 2020/2021. Всего было зарегистрировано и проанализировано 242138 технико-тактических действий в 25 играх с участием команд «Манчестер Сити» (Манчестер, Англия), “Челси» (Лондон, Англия), «Олимпик» (Марсель, Франция), «Олимпиакос» (Пирей, Греция), «Порту» (Порту, Португалия), «Краснодар» (Краснодар, Россия), «Ренн» (Ренн, Франция), «Севилья» (Севилья, Испания), «Атлетико» (Мадрид, Испания), «Боруссия» (Дортмунд, Германия), «Боруссия» (Менхенгладбах, Германия), «Реал» (Мадрид, Испания), «Пари Сен-Жермен» (Париж, Франция). Для решения поставленных задач в работе применялись следующие методы исследования: анализ научно-методической литературы, регистрация технико-тактических действий, методы математической статистики. Результаты: в статье представлены данные, характеризующие особенности выполнения оборонительных и атакующих ТТД командами высокого уровня по итогам игр Лиги чемпионов УЕФА сезона 2020/2021. Разработаны модельные показатели выполнения передач мяча (различных по назначению, дистанции, направлению, траектории, способу выполнения), ударов в створ (ногой и головой из разных зон футбольного поля), обводок соперника, единоборств за мяч, отборов, перехватов, выбивания мяча, блокирования ударов в ворота. Выводы: данные проведенного исследования свидетельствуют о различиях в структуре соревновательной деятельности команд разного уровня в играх Лиги чемпионов УЕФА сезона 2020/2021. Команда-победительница превосходила своих соперников почти по всем показателям.
\end{abstract}

Ключевые слова: футболисты, модельные показатели, ТТД, передачи мяча, удары, перехваты, отборы.

Abstract. Andrii Pertsukhov, Borys Beziazychnyi, Viktoria Khudiakova. Comparative characteristics of TTA of the world's leading football clubs. Purpose: to determine model indicators of performing technical and tactical actions by high-level teams. Material and methods: registration of technical and tactical actions was carried out on the example of games of participating teams in the 2020/2021 UEFA Champions League. A total of 242138 technical and tactical actions in 25 games of the teams «Manchester City» (Manchester, England), "Chelsea» (London, England), «Olympique» (Marseille, France), "Olympiacos» (Piraeus, Greece), «Porto» (Porto, Portugal), «Krasnodar» (Krasnodar, Russia), «Rennes» (Rennes, France), «Sevilla» (Sevilla, Spain), "Atletico» (Madrid, Spain), «Borussia» (Dortmund, Germany), "Borussia» (Monchengladbach, Germany), «Real» (Madrid, Spain), "Paris Saint-Germain» (Paris, France) were registered and analyzed. The following research methods were used to solve the tasks: analysis of scientific and methodological literature, registration of technical and tactical actions, methods of mathematical statistics. Results: the article presents data characterizing features of the defensive and attacking TTA by high level teams based on the results of the 2020/2021 UEFA Champions League games. Model indicators of making the ball passes (different in purpose, distance, direction, trajectory, method of performance), shots on target (with a foot and head from different areas of the football field), dribbling of an opponent, aerial duels, tackles, interceptions, knocking out the ball, blocking strikes into the goal have been developed. Conclusions: the data of the study show differences in the structure of competitive activity of different level teams in the games of the 2020/2021 UEFA Champions League. The winning team outnumbered their rivals in almost every indicator.

Keywords: football players, model indicators, ТТД, passes, shots, interceptions, tackles attempted.

\title{
References
}

1. Golomazov, S., Chirva, B. (2000), «Model characteristics of play in the penalty area», Teoriia i praktika futbola, №2 (6), pp. 2-4. (in Russ.)

2. Golomazov, S., Chirva, B. (2003), «Morphological signs of highly qualified goalkeepers», Teoriia i praktika futbola, №2 (18), pp. 25-28. (in Russ.)

3. Guba, V., Kuzmenko, lu., Stroeva, I., Chernova, V. (2001), «Morphological characteristics of football players 17-18 years old», Teoriia i praktika futbola, №3 (11), pp. 17-19. (in Russ.)

4. Zhurid, S. N. (2007), «Model characteristics of technical and tactical actions of young footballers aged 15 and 17 years of different game roles», Slobozhanskii naukovo-sportivnii visnik, №12, pp. 93-97. (in Russ.)

5. Kostiukevych, V. M. (2006), «Model indicators of functional readiness of football players», Zbirnyk naukovykh prats z haluzi fizychnoi kultury i sportu, №10, p. 78. (in Ukr.)

6. Kostiukevich, V. M. (2006), Upravlenie trenirovochnym protcessom futbolistov v godichnom tcikle podgotovki. Vinnitca: Planer, 683 p. (in Russ.)

7. Lebediev, S. I., Sleman, Rebaz (2015), «Analysis of indicators of competitive activity and special technical training of football players aged 10-12», Slobozhanskyi naukovo-sportyvnyi visnyk, №5 (49), pp. 52-56. (in Ukr.)

8. Maksymenko, I. H., Kostiunin, A. V. (2007), «Analysis of indicators of competitive activity of football players of the national team of Ukraine at the World Cup 2006», Slobozhanskyi naukovo-sportyvnyi visnyk, № 11, pp. 47-54. (in Ukr.)

9. Martirosov, E., Baluchi, R. (2006), «Morfologicheskie osobennosti futbolistov vysokoi kvalifikatcii raznykh amplua», FutbolProfi, №2, pp. 60-65. (in Russ.)

10. Mulyk, V. V., Perevoznyk, V. I., Pertsukhov, A. A. (2015), «Characteristics of episodes of the game in the penalty area of the opposing team», Slobozhanskyi naukovo-sportyvnyi visnyk, №3 (47), pp. 75-79. (in Ukr.)

11. Perevoznik, V. I., Pertcukhov, A. A. (2007), «Comparative analysis of performance of technical and tactical actions by experienced footballers and footballers aged 17-19», Slobozhanskii naukovo-sportivnii visnik, №11, pp. 115-119. (in Russ.)

12. Perevoznik, V. I., Pertcukhov, A. A. (2016), «Model indicators of the preparedness of highly qualified football players», Problemy i perspektivy razvitiia sportivnykh igr i edinoborstv v vysshikh uchebnykh zavedeniiakh, p. 34-39. (in Russ.)

13. Perevoznik, V. I., Pertcukhov, A. A. (2017), «Model indicators of the competitive activity of highly qualified football players», Problemy i perspektivy razvitiia sportivnykh igr i edinoborstv $v$ vysshikh uchebnykh zavedeniiakh, p. 41-45. (in Russ.)

14. Perevoznik, V. I., Pertcukhov, A. A. (2018), "Age and anthropometric indicators of highly qualified football players", Slobozhanskii naukovo-sportivnii visnik, №6 (68). pp. 65-69. (in Russ.)

15. Perevoznik, V. I., Pertcukhov, A. A. (2018), «Functional readiness of highly qualified football players», Problemy i perspektivy razvitie sportivnykh igr i edinoborstv $v$ vysshikh uchebnykh zavedeniiakh, pp. 60-65. (in Russ.)

16. Pertcukhov, A. A. (2011), «Interrelation of indicators of overall body dimensions and functional readiness of football players 17-19 years old», Fizicheskoe vospitanie studentov, №4, pp. 64-66. (in Russ.)

Перцухов, А., Без'язичний, Б., Худякова, В. (2021), «Порівняльні характеристики ТТД провідних футбольних клубів світу»
Слобожанський науково-спортивний вісник, № 3(83), С. 68-76, doi:10.15391/snsv.2021-3.010 
17. Pertcukhov, A. A. (2017), «Peculiarities of passing the ball by Leicester City football players in the England Championship 2015-2016», Slobozhanskii naukovo-sportivnii visnik, №3 (59), pp. 101-105. (in Russ.)

18. Pertcukhov, A. A. (2018), "Characteristics of effective strikes into the goal in the games of highly qualified teams», Sportivnye igry, №2 (8), pp. 54-60. (in Russ.)

19. Pertsukhov, A. A. (2020), «Intensity and efficiency of high-level football players' pressure», Sportyvni ihry: elektronnyi naukovyi zhurnal, №2 (16), pp. 50-57. (in Ukr.)

20. Pertcukhov, A. A., Perevoznik, V. I. (2019), «Motor activity of highly qualified football players in conditions of competitive activity», Sportivnye igry, №1 (11), pp. 32-39. (in Russ.)

21. Pertsukhov, A. A., Shalenko, V. V. (2021), "Model characteristics of leading football players of different game roles», Slobozhanskyi naukovo-sportyvnyi visnyk, №1 (81), pp. 47-58. (in Ukr.)

22. Platonov, V. N. (2004), Sistema podgotovki sportsmenov v olimpiiskom sporte. Obshchaia teoriia i ee prakticheskoe prilozhenie. Kiev: Olimpiiskaia literatura, 808 p. (in Russ.)

23. Shalenko, V. V., Pertcukhov, A. A. (2016), «Anthropometric indicators of highly qualified football players», Problemy i perspektivy razvitiia sportivnykh igr i edinoborstv v vysshikh uchebnykh zavedeniiakh, pp. 53-56. (in Russ.)

24. Shamardin, V. N. (2002), Modelirovanie podgotovlennosti kvalifitcirovannykh futbolistov. Dnepropetrovsk: Porogi, 200 p. (in Russ.)

25. Bangsbo, J. (1993), The physiology of soccer - with special reference to intense intermittent exercise. HO + Storm, 155 p. (in Eng.)

26. Bangsbo, J. (1994), «Energy demands in competitive soccer», J. Sports Sci, №12, pp. 5-12. (in Eng.)

27. Bangsbo, J. (1998), «The physiological profile of soccer players», Sports Exercise and Injury, №4, pp. 144-150. (in Eng.)

28. Bangsbo, J., Norregaard, L., Thorsoe, F. (1991), «Activity profile of competition soccer», J. Sports Sci, №16 (2), pp. 6-110. (in Eng.)

29. Brewel, J., Davis, J.A. (1992), «A physiological comparison of English professional and semi-professional soccer players», J. Sports Sci, №10, pp. 7-146. (in Eng.)

30. Broad, E.M., Burke, L.M., Cox, G.R., Heeley, P, Riley, M. (1996), «Body weight changes and voluntary fluid intakes during training and competition sessions in team sport», Int J Sport Nutr, №6 (3), pp. 20-307. (in Eng.)

31. Casajus, J. A. (2001), «Seasonal variation in fitness variables in professional soccer players», J. Sports Med. Phys. Fitness, №41 (4), pp. 9-463. (in Eng.)

32. Davies, J. A., Brewer, J., Atkin, D. (1992), «Preseasonal physiological characteristics of English first and second division soccer players», Journal of Sports Sciences, №10, pp. 541-547. (in Eng.)

33. Dupont, G., Akakpo, K., Berthoin, S. (2004), «The effect of in-season, high-intensity interval training in soccer players», J Strength Cond Res, №18 (3), p. 9-584. (in Eng.)

34. Heller, J., Prochazka, L., Bunc, V. (1992), «Functional capacity in top league football players during the competitive season», J. Sports Sci, №10, p. 150 (in Eng.)

35. Pertsukhov, A., Beziazychnyi, B., Khudiakova, V. (2020), «Features of goal kicks by football players in games of high-level teams", Slobozhanskyi herald of Science and Sport, Vol 8, No 1, P. 59-62. (in Eng.)

36. Pertsukhov, A., Perevoznick, V., Shalenko, V., Zhurid, S., Khudyakova, V., Koval, S. (2018), «Functional preparedness of football players with different qualifications", The Journal of Physical Education and Sport is now a registered trademark (all rights reserved), №104, pp. 710-714. (in Eng.)

37. Pertsukhov, A., Shalenko, V. (2020), "Features of effective goal shots by football players in games of high level teams», Slobozhanskyi herald of Science and Sport, Vol 8, No 2, pp. 17-28. (in Eng.)

Received: 17.05 .2021$.

Published: 23.06.2021

\section{Відомості про авторів / Information about the Authors}

Перцухов Андрій Анатолійович: к.фіз.вих; Харківська державна академія фізичної культури: вул. Клочківська, 99, м. Харків, 61058, Україна.

Перцухов Андрей Анатольевич: к. физ.восп; Харьковская государственная академия физической культуры: ул. Клочковская, 99, г. Харьков, 61058, Украина.

Andrii Pertsukhov: PhD (Physical Education and Sport); Kharkiv State Academy of Physical Culture: Klochkivska 99, Kharkiv, 61058, Ukraine.

ORCID: https://orcid.org/0000-0003-1525-8488

E-mail: pertsukhov_82@ukr.net

Без'язичний Борис Іванович: д.пед.н; Харківська державна академія фізичної культури: вул. Клочківська, 99, м. Харків, 61058, Україна.

Безъязычный Борис Иванович: д.пед.н; Харьковская государственная академия физической культуры: ул. Клочковская, 99, г. Харьков, 61058, Украина.

Borys Beziazychnyi: D. Sc. in Pedagogic Sciences; Kharkiv State Academy of Physical Culture: Klochkivska 99, Kharkiv, 61058, Ukraine.

ORCID: https://orcid.org/0000-0002-5256-9261

E-mail: borys19900star@ukr.net

Худякова Вікторія Борисівна: к.фіз.вих; Харківська державна академія фізичної культури: вул. Клочківська, 99, м. Харків, 61058, Україна.

Худякова Виктория Борисовна: к. физ.восп; Харьковская государственная академия физической культуры: ул. Клочковская, 99, г. Харьков, 61058, Украина.

Viktoria Khudiakova: PhD (Physical Education and Sport); Kharkiv State Academy of Physical Culture: Klochkivska 99, Kharkiv, 61058, Ukraine.

ORCID: https://orcid.org/0000-0003-1376-6761

E-mail: viktoriakhudyakovakhdafk@gmail.com 